\title{
A CONTENT-BASED ANALYSIS OF FUZULI'S AZERBAIJANI TURKISH POEMS TESTED AGAINST QUR'ANIC THEMES
}

\author{
Mohammad Amin Mozaheb ${ }^{{ }^{*}}$, Mostafa Shahiditabar ${ }^{2}$ \\ ${ }^{1}$ Asist. Prof. Dr., Department of Foreign Languages, Imam Sadiq (A) University, IRAN, \\ mozaheb.ma@gmail.com \\ ${ }^{2}$ Lecturer Mr., Department of Foreign Languages, Imam Sadiq (A) University, IRAN, \\ m_shahidi2005@yahoo.com \\ ${ }^{*}$ Corresponding author
}

\begin{abstract}
Over the decades, it was shown that world literature and culture are two inseparable parts. Religion which is part of a nation's culture can be linked to literature. Ever since the day the holy Qur'an has been revealed to Prophet Muhammad (PBUH), a large number of scholars have worked on it in terms of translation, content etc. The present study aims at analyzing Azerbaijani poet, writer and thinker Muhammad bin Suleyman aka Fuzuli's Azerbaijani Turkish poems in terms of Qur'anic themes. The corpus of the study consisted of some of his poems which were selected randomly and scanned in order to see the common themes used in them. Then, the themes were tallied and shown in relevant tables containing frequencies and percentages. The results of the study showed that Fuzuli's main Qur'anic theme was God (i.e., frequency: 13 times) and then he used several other themes such as Paradise and Resurrection Day. All in all, the findings of this study, which can be beneficial for those interested in carrying out research studies in literature and culture, demonstrate that Fuzuli utilized Qur'anic themes such as God, worship, religion and Hell in his poems in an attempt to show his knowledge with regard to Islamic customs and culture.
\end{abstract}

Keywords: Content-based analysis, Fuzuli, Poetry, Qur'an, Islamic themes

\section{INTRODUCTION}

Islam is a monotheistic religion practiced by over two billion people in different continents of the world (Muslim Population, 2014). Muslims are the followers of this religion who "believe in one God (Allah) and blissfully follow the teachings of the final Prophet Muhammad (PBUH)" (Siddiqui, 2015, p. 7). Muslims have a book called the holy Qur'an which is written in Arabic. According to the American Heritage Dictionary (2011, p. 721), Qur'an also written as Koran is "the sacred text of Islam," which contains "the revelations of God to [Prophet] Muhammad [PBUH] through the angel Gabriel". According to Siddiqui (2015, p. 1), "the Qur'an contains valuable information and provides one stop solution for humanity. It is free from contradictions and discrepancies". The religious book of Muslims has a total of 114 chapters, also known as Surahs, which vary in length from three to 286 verses, called Ayahs (Abro, Naqvi \& Hussain, 2012).

Ever since the day the holy Qur'an has been revealed to Prophet Muhammad (PBUH), a large number of scientists have worked on it in terms of its translation into different languages such as English, Persian, and Turkish etc. For instance, Halimah (2014, p.122) evaluated several English versions of the translation of 
the holy Qur'an utilizing "concepts, principles and norms as parameters for discussion and analysis". He concluded that the English speaking world needs a "mechanism that will help using the formation of a standardized version of an explanatory translation of the meanings of the Qur'an that is authoritative in form and content". Some other scholars have studied the translation of the holy Qur'an (e.g., Abdul-Raof, 2001 \& 2005; Al-Shabab, 2008 \& 2012; Bobzin 1993; Mustafa, 2011; Versteegh, 1991). The language of Qur'an which is "unsurpassed in its accuracy of meaning and expression" has also attracted the attention of academics, poets and literary figures across the world (Islamic Bulletin, 2015, p.1). Notable British Orientalist and translator, Forster Fitzgerald Arbuthnot (1887, p. 5) states that “...and that though several attempts have been made to produce a work equal to it [Qur'an] as far as elegant writing is concerned, none has as yet succeeded." The Qur'an has challenged all humanities to do their best and write a single chapter like it. The Qur'an states:

"If you are in doubt of what We have revealed to Our Messenger, then produce one chapter like it, call upon all your helpers, besides Allah, if you are truthful." Surah al-Baqarah (The Heifer) 2: 23.

"Or do they say: "He (Prophet Muhammad [PBUH]) has forged it (this Qur'an)?" Nay! They believe not! Let them then produce a recitation like it (the Qur'an) if they are truthful." Surah at-Toor (The Mount) 52: 33-34.

Considering this unmet challenge of Qur'an which is a language-miracle, poets and writers used Qur'anic themes in their literary works. As an example, Khwajeh Shams al-Din Muhammad Hafez-e Shirazi also known by his pen name Hafiz, a 14th-century Iranian mystic and poet, used themes found in Qur'an in a number of his poems. In this regard, Moradian, Adel and Tamri (2014, p. 69) state that "The Persian poets tried their best to compose pieces of poetry dealing with diverse points and various themes following the Arabic traditions. As an example, Hafiz, the great Iranian poet in 800 A. D., took many of the themes of his poetry from Arabic poets and the Qur'an (The holy book of Muslims)."

Referring to Hafiz and one of his sonnets which is linked to the holy Qur'an, Nazari $(2011$, p. 140) said that:

The holy Qur'an exerted great influence on Hafiz Sonnets. Sometimes this influence has been symbolic and open to different poetic and figurative interpretations. Hafiz has adopted Qur'anic words and expressed them in beautiful ways with strong effect. It seems there is a high amount of correspondence between Hafiz's Sonnet 216 and the story of Solomon in the Qur'an (Surah Naml) in wording, notions, themes and artistic and symbolic expressions. Clearly, Hafiz based his poem on this Qur'anic story and Zemakhshari's interpretation of Verse 44 in Naml. Fairy, Saba Queen, dissatisfaction of Jens as to Solomon's marriage to Saba Queen are among the themes Hafiz incorporated into his poem and presented in an artistic sonnet. For example, he took "nazar" (glance, look) from Solomon's words and used it in a phrase in his poem to refer to "wise words" and "wiseman". It is difficult to discover this connection at first glance. However, this technique makes Hafiz's poetry very interesting and enjoyable to read.

Among poets and literary figures who have used Qur'anic themes is an Azerbaijani poet, writer and thinker Muhammad bin Suleyman known as Fuzuli. Born in the holy city of Karbala in Iraq, Fuzuli wrote his collected poems in three different languages (i.e., Arabic, Persian and Turkish). He was also a renowned figure in mathematics and astronomy. According to Britannica (2014, p.8), "Fuzuli composed poetry with equal facility and elegance in Turkish, Persian, and Arabic. Although his Turkish works are written in the Azerbaijani [Turkish] dialect, he had a thorough knowledge of both Ottoman and Chagatai Turkish literary traditions."

Surveying the related literature, the researchers of the present study found out that no one has worked on Fuzuli's Turkish divan of poems in terms of Qur'anic themes. So, the present study aims to answer the following research question:

To what extent Fuzuli has been under the influence of the holy Qur'an while writing his poems?

\section{METHOD}

The current study is a qualitative study which aims at analyzing the Turkish divan of Fuzuli in terms of Qur'anic themes. The authors of the present study used content-based analysis in order to see how Fuzuli used and represented Qur'anic themes in his Turkish poems.

\subsection{Corpus}

The corpus of the present study consists of 32 sonnets which were selected randomly from Fuzuli's Turkish divan. The book includes 329 sonnets. 


\subsection{Procedure}

In order to find an answer for the posed research question, the researchers meticulously studied the randomly-selected poems of Fuzuli's Azerbaijani Turkish divan and found a number of frequent themes such as God, Worship and Resurrection Day repeated in the poems. Then, the number of the themes were tallied using content analysis which "is a research technique for making replicable and valid inferences from texts (or other meaningful matter) to the contexts of their use" (Krippendorff, 2004, p. 18). After counting the relevant themes found in the poems, the researchers showed them in a table containing frequency and percentages. Finally, a number of Fuzuli's verses were discussed in full details.

\section{RESULTS AND DISCUSSION}

According to Table 1, Fuzuli used a large number of themes found in the holy Qur'an. For instance, a paramount theme in his poems was God used 13 times or 18.84 percentages. Another frequent theme is Gibla and Mihrab with 10.14 percentages or seven times. According to Britannica (2014, p. 23) Gibla "also spelled qibla or kiblah [is] the direction of the sacred shrine of the Ka'bah in Mecca, Saudi Arabia, toward which Muslims turn five times each day when performing the salat (daily ritual prayer)... In a mosque, the qiblah is indicated by the mihrab, a niche in the mosque's interior wall facing Mecca". Similarly, Giamat also Qayamat (i.e., Resurrection Day) was used seven times meaning 10.14 percentages. Worship was utilized three times or 4.37 percent. Additionally, Paradise-related words such as Jinnah and Tooba were used four times or 5.79 percentages. In a similar vein, Mo'men, religion and Kafir were written in Fuzuli's selected poems three times each. According to Ummah (2015, p.1):

Kafir is not simply a non-Muslim.... Kafir is one that COVERS up the truth! Classical Arabic language that is what a Kafir is.....If someone doesn't know the truth then how can they cover it up?!Being simple not [sic] Muslim does not make one a Kafir...What would make one a Kafir is [sic] they learn about Islam recognize it is the truth and in insolence turn away from Islam. A good example of a Kafir from the Qur'an would be pharaoh...HE had seen all the signs manifest right before his eyes...He knew Allah was the only God and he covered the truth up because of his arrogance...This is why when he was drowning he said he believed in the God of Moses...So all the time he had been covering up the truth.

Then, repentance and idol were used two times (i.e., 2.89 percentages each respectively) in the poems. Islam Awareness (2015, p. 2) describes repentance in Islam in the following way:

Feelings of remorse and guilt are natural reflections of sinning, if the person who has sinned has a conscious which is alive. After committing a sin, a person who fears Allah and give high respect to Him would feel a sense of despondency and despair thinking, "How will God forgive me for this sin?" However, it is noteworthy that despairing of God's mercy is in itself one of the major sins in Islam for God is ever merciful, ever forgiving.

As He says in the Qur'an:

Do not despair of God's mercy; He will forgive you of all your sins. Qur'an (39:53).

In another verse, Allah says:

And He wishes to forgive you Qur'an (4:146).

Hell was also used two times meaning 2.89 percentages. Other Islamic themes were used 20 times or 28.93. The results presented in Table 1 showed that Fuzuli was under the influence of the holy Qur'an and used several different Qur'anic themes in his poems.

Table 1: Frequency of Qur'anic Themes used in the randomly-selected poems of Fuzuli

\begin{tabular}{|c|c|c|}
\hline Themes & Frequency & Percentage \\
\hline God & 13 & 18.84 \\
\hline Gibla (Qibla) \& Mehrab & 7 & 10.14 \\
\hline Giamat or Qayamat (Resurrection Day) & 7 & 10.14 \\
\hline Paradise-related words such as Jinnah and Tooba & 4 & 5.79 \\
\hline
\end{tabular}




\begin{tabular}{|c|c|c|}
\hline Worship (Sijdah \& Tasbih) & 3 & 4.37 \\
\hline Muslim \& Mo'men & 3 & 4.37 \\
\hline Religion & 3 & 4.37 \\
\hline Kafir & 3 & 4.37 \\
\hline Repentance & 2 & 2.89 \\
\hline Cult Image (Idol) & 2 & 2.89 \\
\hline Hell & 2 & 2.89 \\
\hline Other Islamic Themes & 20 & 28.98 \\
\hline Total & 69 & 100 \\
\hline
\end{tabular}

Some of the examples of Qur'anic themes used in Fuzuli's poems appear below:

Ey ki, əhli-eşqə söylərsən məlamət, tərkin et!

Söylə kim, mümkünmüdür təğyiri-təqdiri-Xuda?

$$
\text { سؤيله كيم، موموكون دور تشؤيلرسن ملامت، تركين ائت }
$$

Oh you, who blame Lovers, finish your blame

Say: who can change the Fate decided by Allah?

In this verse, the poet talks about the fate that is determined by Allah. It is seen in this poem that Fate cannot be changed unless Allah decides. According to Islamic philosophy, human beings can change their fates by their deeds. Allah and Fate are the two Islamic concepts used here.

Sicdədir hər qanda bir bot görsəm ayinim mənim

Xah kafər xah mümin dut budur dinim mənim

$$
\text { خو اه كافر خور هر قاندا بير بُت كؤرسم آيينيم منيم }
$$

If I see any blood on Idol, I will prostrate, this is my belief,

Whether the Idol is Kafir or Believer (Mo'men), this is my belief.

Here, the poet just prostrates when there is a drop of blood. Prostration is the highest degree of worship.

Cənnəti kuyuna zühd əhli münasib desələr

Nə münasib ki qılam bir neçə nadan ilə bəhs

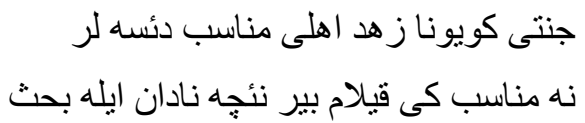

If the Hermits announce that Paradise is suitable,

I will argue with some fools then.

As far as this verse is concerned, the poet does not want Paradise (which is the Land of Peace and blessing), but he wants something that is more valuable than Paradise that is (Allah). He points out that if the Hermits choose Paradise (but not Allah) then they are just stupid.

Zahidin təni ilə döndərdim uzum mehrabidən 
Necə bulmaz əcr beyni kafər müsəlman eyləyin

$$
\text { زائجه بولماز اجر بينه دؤندرديم اوزوم محر ابدان }
$$

Oh Hermit, I turned my face from Mihrab

How is it possible to consider no differences between a Muslim and a Kafir?

The poet draws a separating line between a Muslim and a Kafir in this verse. To put it simply, three Islamic concepts as Mihrab, Muslim and Kafir were used in this verse.

\section{CONCLUSION}

In conclusion, the results of the present study confirmed that Fuzuli used Islamic themes and Qur'anic themes while writing his poems in an attempt to show his interest and responsibility toward the holy Qur'an. Additionally, the analysis and the different vocabularies used by Fuzuli showed that he was interested in both Azeri and Iranian cultures. In other words, the findings of this study confirmed what Pak Aein (2013) noted about Fuzuli who is the linking piece that can connect Iranian culture with the culture of people living in Azerbaijan. Pak Aein (2013, p. 1) also continued to say that "he [Fuzuli] played an important role in retaining unity between Iranians and Azeris."

This study has some implications for those interested in Qur'anic studies and content-based analyses of literary works. The results of this study can motivate stakeholders in different disciplines to do similar content-based analysis on other literary figures coming from different countries.

\section{REFERENCE LIST}

Abdul-Raof, H. (2005). "Pragmalinguistic Forms in Cross-Cultural Communication: Contributions from Qur'an Translation". Intercultural Communication Studies, 14 (4).

Abdul-Raof, H. (2001). Qur'an Translation: Discourse. Texture and Exegesis. Richmond: Curzon.

Abro, B., Naqvi, A. B., \& Hussain, A. (2012). "Qur'an Recognition for the Purpose of Memorization Using Speech Recognition Technique. In Multitopic Conference (INMIC), 2012 15th International (pp. 30-34). IEEE.

Al-Shabab, O. S. (2012). Textual Source and Assertion: Sale's Translation of the Holy Quran. Journal of King Saud University-Languages and Translation, 24 (1).

Al-Shabab, O. S. (2008). From Necessity to Infinity: Interpretation in Language and Translation. Janus Publishing Company.

Arbuthnot, F. F. (1887). Persian Portraits: A Sketch of Persian History, Literature and Politics. London: Quaritch.

Bobzin, H. (1993). "Latin Translations of the Qur'an. A Short Overview”. Der Islam, 70 (2).

Britannica, E. (2014). Encyclopedia Britannica. Retrieved from www. britannica.com

Halimah, A. M. (2014). "Translation of the Holy Qur'an: A Call for Standardization". Advances in Language and Literary Studies. 5 (1).

Islamic Bulletin (2015). Understanding Islam and Muslims. Retrieved from http://www.islamicbulletin.org/

Islam Awareness (2015). Repentance. Retrieved from http://www.islamawareness.net/Repentance/repentance.html

Krippendorff, K. (2004). "Reliability in Content Analysis". Human Communication Research, 30 (3).

Mifflin, H. (2011). The American Heritage Dictionary of the English Language. Boston: Boston Publisher.

Moradian, M., Adel, M. \& Tamri, M. (2014). "An Intercultural Rhetoric Investigation of the Discourse Topic in the English and Persian Editorials". NATIONALPARK-FORSCHUNG IN DER SCHWEIZ (Switzerland Research Park Journal), 103 (1).

Mustafa, H. (2011). "Quran". In Baker, M \& Saldanha, G (ed.) Routledge Encyclopedia of Translation Studies. 2 nd edition, Routledge.

Muslim Population, (2014). World Muslim population. Retrieved from 
http://www.muslimpopulation.com/World/

Nazari, A. (2011). "The Influence of Solomon's Story in the Qur'an on Hafiz Sonnet 216". Studies on Arabic Language and Literature, 1 (4).

Pak Aein, M. (2013). Mystical Elaborations on Fuzuli's Sonnets Unveiled in Baku. Retrieved from http://www.ibna.ir/en/doc/naghli/171360/mystical-elaborations-on-fuzuli-s-sonnets-unveiled-in-baku

Siddiqui, M. K. (2015). "A Review of Qur'anic Web Portals through Data Mining". VAWKUM Transaction on Computer Sciences, 5(2).

Ummah (2015). Forum. Retrieved from http://www.ummah.com/forum/showthread.php?77922-Truemeaning-of-Kafir

Versteegh, K. (1991). "Greek Translations of the Qur'an in Christian Polemics (Ninth Century A.D)". Zeitschrift der Deutschen Morgenlandischen Gesellschaft 141 (1). 